\title{
A dominant interfering Myb mutant causes apoptosis in $T$ cells
}

\author{
Deborah Taylor, Pratipa Badiani, and Kathleen Weston ${ }^{1}$ \\ CRC Centre for Cell and Molecular Biology, Institute of Cancer Research, 237 Fulham Road, London SW3 6JB, UK
}

\begin{abstract}
The c-Myb transcription factor is required for the production of most hemopoietic lineages, but information is sparse about its mode of action and the key genes it regulates. We have made an inducible dominant interfering Myb protein, by creating a chimera comprising the DNA binding domain of c-Myb, the Drosophila Engrailed repressor domain, and a modified estrogen receptor hormone binding domain. When expressed in the murine thymoma cell line EL4, activation of this mutant results in a significant proportion of the cell population undergoing apoptosis, as assessed by nuclear breakdown and DNA fragmentation, but has no apparent effect on cell-cycle progression. The apoptotic phenotype is mirrored during thymopoiesis in transgenic mice expressing dominant interfering $M y b$ mutants; their $T$ cells are fragile both in vivo and in vitro. Induction of the Myb dominant interfering mutant in EL4 cells correlates with down-regulation of bcl-2, but does not affect transcription of other bcl-2 family members; conversely, overexpression of bcl-2 in the transgenic mouse model rescues thymocytes from death. Analysis of the $b c l-2$ promoter by run-on transcription, bandshifting, and transient expression assays shows that it is a direct target of Myb. These data suggest a new and important role for $M y b$ proteins as regulators of cell survival during hemopoiesis.
\end{abstract}

[Key Words: Myb; apoptosis; bcl-2; T cells; transcriptional control]

Received July 5, 1996; revised version accepted August 28, 1996.

The Myb family of transcription factors comprises three members: c-Myb, an activator expressed almost exclusively in hemopoietic lineages; A-Myb, likewise an activator, but expressed more promiscuously; and B-Myb, also expressed in many tissues, whose function remains controversial (Foos et al. 1992; Tashiro et al. 1995; Thompson and Ramsay 1995) but whose biological properties to date are similar to those of c-Myb (Arsura et al. 1992; Sala and Calabretta 1992). All three proteins share a highly conserved DNA binding domain and recognize the same binding site. Little is known about the targets regulated by Myb proteins. A number of genes whose upstream regions contain $\mathrm{Myb}$ binding sites have been described (Thompson and Ramsay 1995), but with a few exceptions it is unclear whether in vivo regulation is occurring.

Previous studies have proposed that $\mathrm{c}-\mathrm{Myb}$ is an important regulator of the cell cycle. c-myb mRNA can be detected at low levels in some nonhemopoietic cell lines, such as chick embryo fibroblasts (CEFs), in a cell cycle-dependent manner, such that c-myb mRNA levels are maximal during late $G_{1}$ (Thompson et al. 1986). In the T-cell lineage, although there seems to be no cellcycle regulation of expression in immature thymocytes (Thompson et al. 1986), levels of c-myb mRNA peak at the $G_{1} / S$ transition following mitogenic stimulation of

${ }^{1}$ Corresponding author. peripheral T cells (Stern and Smith 1986; Crabtree 1989). Treatment of many hemopoietic cell lines and also of human peripheral blood lymphocytes and bone marrow cells with c-myb antisense oligonucleotides blocks proliferation, possibly by inhibiting the $\mathrm{G}_{1} / \mathrm{S}$ transition (for review, see Calabretta 1991), although recent data indicate that the effects of the oligonucleotides used may be nonspecific (Burgess et al. 1995). B-Myb expression is also cell cycle-regulated (Lam and Watson 1993; Lam et al. 1995), and may also be involved in $G_{1} / S$ progression (Lin et al. 1992).

c-Myb plays a vital role during hemopoietic differentiation. Early studies showed that the protein was detectable in most hemopoietic lineages and that its expression declined as cells matured and ceased to divide. Down-regulation of c-Myb may be essential for maturation to occur in some lineages (Graf 1992). Confirmation that $\mathrm{c}-\mathrm{Myb}$ is required for normal hemopoiesis came with the demonstration that inactivation of the c-myb gene by homologous recombination results in the death of $-/-$ mice at $\mathrm{d} 15$ in utero, attributable to a failure of hepatic erythropoiesis (Mucenski et al. 1991). All other hemopoietic lineages, with the exception of megakaryocytes, were also gravely affected; progenitor cells were still present, but in greatly reduced numbers. As these cells were still capable of differentiation, it was suggested that $\mathrm{c}-\mathrm{Myb}$ protein might normally regulate the switch between growth and differentiation by maintaining progenitors in a proliferative state. Loss of $\mathrm{c}-\mathrm{Myb}$ expression would then result in an inability to prolifer- 
ate, and cells would enter the differentiation pathway instead.

The embryonic mortality of c-myb-null mice made it necessary to develop other techniques to study the consequences of loss of c-Myb expression in the blood cell lineages of live mice. We were specifically interested in the function of $\mathrm{c}-\mathrm{Myb}$ during $\mathrm{T}$-cell differentiation. $\mathrm{c}-\mathrm{Myb}$ is expressed at high levels in immature thymocytes of the thymic cortex, switched off as cells mature, but becomes active again in mature $\mathrm{T}$ cells during their proliferative response to antigen (Stern and Smith 1986). In order to probe the function of $\mathrm{c}-\mathrm{Myb}$ in $\mathrm{T}$ cell development, we created two dominant interfering Myb mutants, one a simple competitive inhibitor comprising the Myb DNA-binding domain (termed MT), and the other an active repressor in which the DNA-binding domain of the protein was fused to the Drosophila Engrailed repressor domain (termed MEnT). These mutants were targeted into the $\mathrm{T}$-cell lineage of transgenic mice (Badiani et al. 1994). Expression of either mutant caused a severe block at an early point in thymopoiesis; furthermore, those $T$ cells that escaped the block and reached maturity in the periphery were unable to proliferate properly in in vitro assays. The MEnT protein was effective at 50 -fold lower expression levels than MT, because of the presence of the active repressor domain.

We wished to extend our studies on the role of $\mathrm{c}-\mathrm{Myb}$ in T-cell development by identifying the Myb-regulated genes that, when turned off in our transgenic mice, were responsible for the observed phenotype. To simplify analysis, we chose to develop an inducible version of the powerful active repressor MEnT and to study its effects in the murine thymoma line EL4. We show here that expression of the Myb dominant interfering allele leads to apoptosis both in EL4 cells and in our original transgenic mice, and we present data correlating this phenomenon with rapid down-regulation of the $b c l-2$ gene. We propose that Myb proteins can function as a safeguard against apoptosis, at least in part via activation of $b c l-2$, and that this role may be of great importance during hemopoiesis.

\section{Results}

Construction and expression of an inducible dominant interfering allele of $M y b$

In order to interfere with the activity of endogenous Myb in EL4 cells, we constructed an inducible version of the Myb-Engrailed chimeric repressor protein MEnT, by adding a modified murine estrogen receptor hormone binding domain (ER HBD) to its carboxyl terminus (Littlewood et al. 1995). The modified ER HBD can be activated only by the estrogen analog 4-hydroxytamoxifen (4-OHT), and proteins fused to it are inert unless 4-OHT is present. The resulting fusion protein, complete with a carboxy-terminal myc 9E10 epitope tag, was designated MERT (Myb-Engrailed-estrogen receptor-tag). Schematic structures of MERT and the control fusion pro- teins ERT (Engrailed-estrogen receptor-tag) and RT (estrogen receptor-tag) are shown in Figure 1A.

The three fusion proteins MERT, ERT, and RT were stable when translated in rabbit reticulocyte lysate, and the synthetic MERT protein retained the ability to bind to the mimA Myb recognition sequence (Ness et al. 1989) from the chicken mim-1 promoter (data not shown). MERT was also able to repress $\mathrm{v}$-Myb-mediated transcription in an inducible fashion. Cotransfection into NIH-3T3 cells of an expression vector encoding the MERT allele, a v-myb expression vector, and a CAT reporter gene carrying five copies of the mimA site upstream of a minimal tk promoter resulted in complete repression of CAT gene expression in the presence of 4-OHT (Fig. 1B, cf. lanes 2 and 4). In the absence of 4-OHT, little or no repression was observed (Fig. 1B, lane 3).

A number of stable clones expressing MERT, ERT, and RT were generated by electroporation of EL4 cells, and representative clones were selected for further analysis. Figure 1C shows a Western blot of protein extracts from control untransfected EL4 cells (lane 1), clones derived from cells transfected with the empty vector $\langle\mathbf{M C l}$; lane 2), RT (R5; lane 3), or ERT (ER1; lane 4) and the two highest expressing clones of MERT (lanes 5 and 6; E16B
A

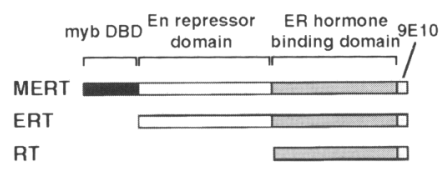

RT

C

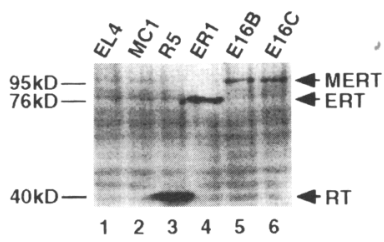

B

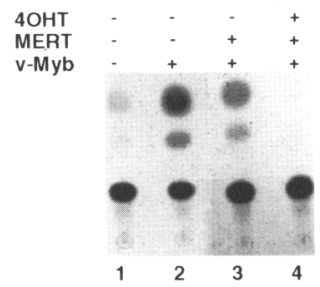

D

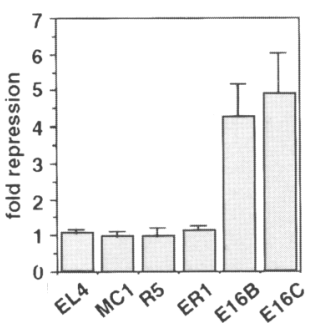

Figure 1. Inducible expression system for the dominant interfering Myb mutant, MERT. (A) Schematic representations of the ER HBD fusion proteins utilized in the experiments: Myb DNA binding domain (myb DBD); Engrailed repressor domain (En repressor domain); ER HBD (ER hormone binding domain); myc 9E10 epitope tag (9E10). (B) CAT assay from NIH-3T3 cells transfected with a $5 \mathrm{mimA}$-tk-CAT reporter plasmid along with the plasmids indicated above each lane, using a reporter-effector-repressor ratio of $1: 5: 15$. A representative CAT assay is shown. $(C)$ Western blot of protein extracts from each cell line, probed with 9E10 antibody. Stably expressed MERT, ERT, and RT proteins and their approximate molecular weights are indicated. $(D)$ Graph showing the fold repression of luciferase activity in the presence of 4-OHT, when each stably transfected EL4 clone was transfected with an SVmim-luciferase reporter gene. Data are standardized for $\beta$-galactosidase activity. 
and E16C), probed with an antibody against the $9 \mathrm{E} 10$ epitope tag. MERT protein was expressed at lower levels than ERT and RT, and all three proteins were of the expected sizes.

To check that the stably transfected MERT proteins were functioning in an appropriate manner and that transcriptional repression was specific, a plasmid containing a luciferase reporter gene under the control of five $\mathrm{Myb}$ binding sites, an SV40 enhancer, and a minimal tk promoter was electroporated into all six clones, together with a control $\beta$-galactosidase expression plasmid. The MERT proteins, but not the controls, should be targeted to the Myb binding sites and actively repress transcription mediated by the neighboring SV40 enhancer. Levels of luciferase activity were measured in the presence and absence of 4-OHT, and the degree of repression was calculated. Figure 1D shows that, on addition of 4-OHT, luciferase levels dropped five- to sixfold in the MERT clones E16B and E16C, but there was no decline in any of the other clones.

\section{Inhibition of Myb activity does not affect the cell cycle}

As Myb proteins have been proposed to be required for cell-cycle progression, we investigated the effects of MERT induction on cell growth and the cell cycle. The MERT lines E16B and E16C, together with the four control lines, were incubated in the presence and absence of $4-\mathrm{OHT}$ for $96 \mathrm{hr}$. Cells were seeded at $1 \times 10^{5}$ per milliliter, samples were taken from each pair of cultures every $24 \mathrm{hr}$, and live cells were counted by trypan blue exclusion. Results are shown in Figure 2A. G418 selection of all six clones had slightly reduced their growth rate relative to parental EL4 cells (open bars). Induction of the ER HBD when alone, or fused to the En repressor domain, was not found to affect cell numbers, as both clones produced indistinguishable growth curves whether or not 4-OHT was present, similar to those of the vector alone clone $\mathrm{MCl}$ (Fig. 2A; light gray bars). However, induction of MERT activity in clones E16B and E16C strikingly reduced the number of live cells at $96 \mathrm{hr}$ by $\sim 50 \%$ (from $1.8 \times 10^{6}$ to $0.8-0.9 \times 10^{6}$; Fig. $2 \mathrm{~A}$; cf. $-4-\mathrm{OHT}$ with $+4-\mathrm{OHT}$, solid bars).

To determine whether the reduction in cell number was due to a cell-cycle block, samples of cells at each time point were studied by flow cytometry, using propidium iodide to stain their DNA. The resulting cellcycle profiles of clone $\mathrm{E} 16 \mathrm{C}$ at the time points 0,72 , and $96 \mathrm{hr}$ are shown in Figure 2B (similar profiles were obtained with E16B). Comparison of the two sets of profiles ( $\pm 4-\mathrm{OHT})$ shows that repression of Myb activity had little or no effect on the cell cycle. Pulsing the cells with bromodeoxyuridine to label DNA at $\mathrm{S}$ phase also indicated that there was no block in transit around the cell cycle (data not shown). The most notable observation from the cell cycle profiles is the appearance of a sub- $G_{1}$ peak in the presence of 4-OHT; this begins to appear by $72 \mathrm{hr}$ and has increased at $96 \mathrm{hr}$ to include around $30 \%$ of cells. As a sub-G $\mathrm{G}_{1}$ peak is indicative of a population of
A

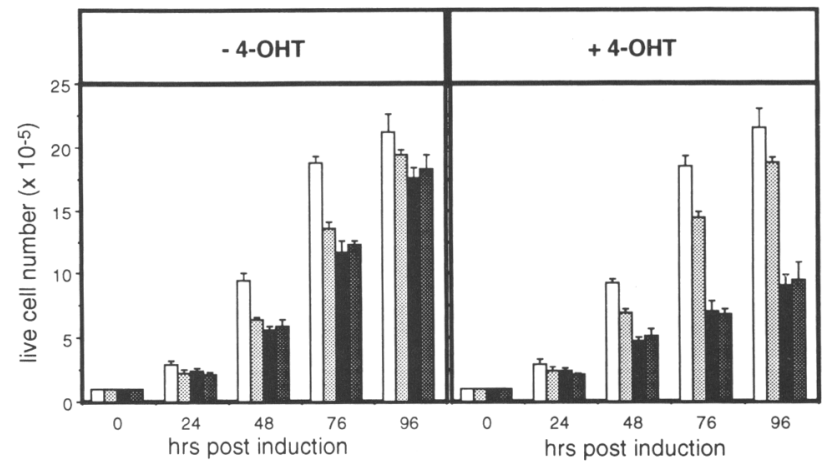

B
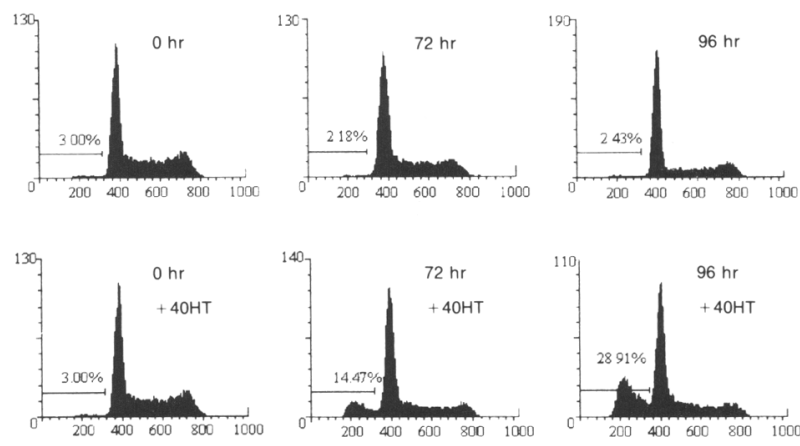

Figure 2. Inhibition of Myb activity by induction of MERT reduces live cell number but does not affect cell cycle. $(A)$ Graph showing the numbers of live cells counted every $24 \mathrm{hr}$ by trypan blue exclusion over 96-hr treatment without 4-OHT (left graph) or with 4-OHT (right graph). Data from parental EL4 cells (open bars), $\mathrm{MCl}$ control clone (light gray bars), and both high expressors of MERT, E16B (solid bars) and E16C (dark gray bars), are shown; ER1 and R5 clones gave similar results as the $\mathrm{MCl}$ clone. (B) Cell-cycle profiles of propidium iodide-stained nuclei of clone E16C $\pm 4-\mathrm{OHT}$ at 0,72 , and $96 \mathrm{hr}$; similar profiles were obtained with clone E16B: $x$-axis, DNA content; $y$-axis, number of events. The percentage of sub- $G_{1}$ (apoptotic) cells is indicated on the histograms. The percentages of cells in the different stages of the cell cycle at $96 \mathrm{hr}$ (calculated to exclude sub- $\mathrm{G}_{1}$ populations) in the absence of 4-OHT, and in the presence of 4-OHT, respectively, were: $\mathrm{G}_{1} 63.3$ and $62.9 ; \mathrm{S}, 15.0$, and 13.3; $\mathrm{G}_{2} / \mathrm{M}, 21.7$ and 23.8 .

cells undergoing apoptosis, these data imply that the observed decrease in the live cell number of the induced MERT clones is not caused by a block in the cell cycle, but is instead a result of cell death.

\section{Inhibition of Myb activity causes apoptosis}

To demonstrate that MERT induction causes apoptosis, rather than necrosis, we examined the effects of induction in more detail. We first performed a simple dead cell count. Cells were grown in the presence and absence of 4-OHT over a 96-hr time course, and samples were taken every $24 \mathrm{hr}$ and scored for the percentage of dead cells in the culture by trypan blue staining. Figure 3A shows the 
A

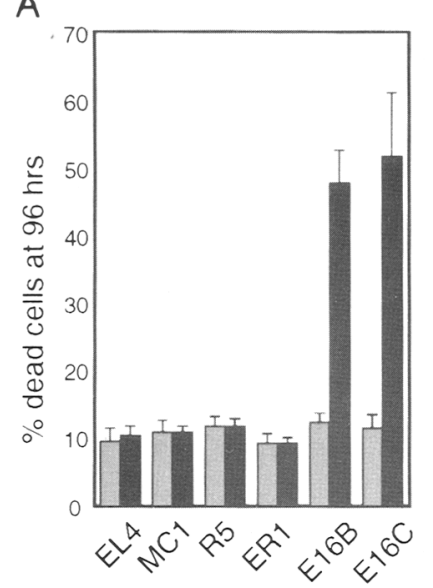

B

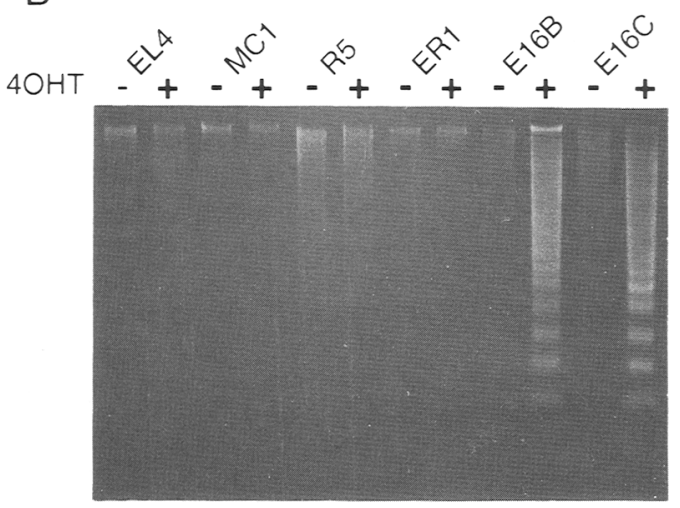

C
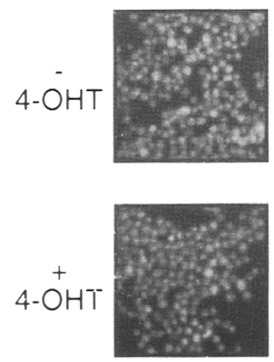

$\mathrm{MC} 1$
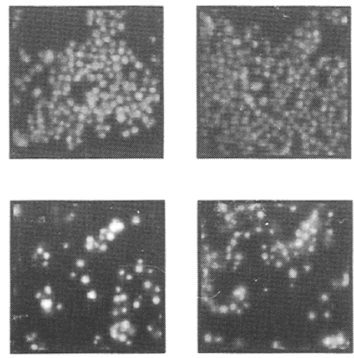

$\mathrm{E} 16 \mathrm{~B}$

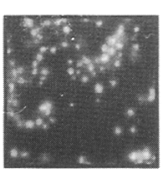

E16C

Figure 3. Inhibition of Myb activity causes apoptosis. $|A|$ Graph of the percentage of dead cells of all control clones and MERT-expressing clones at $96 \mathrm{hr}$ as counted by trypan blue inclusion, when incubated either without 4-OHT (gray bars) or with 4-OHT (solid bars). (B) DNA harvested from $10^{6}$ cells from each of the clones $\pm 4-\mathrm{OHT}$ at $96 \mathrm{hr}$, electrophoresed through a $1 \%$ agarose gel and stained with ethidium bromide. $(C)$ Hoechst 33258 staining of nuclei from $\mathrm{MCl}$ control cells, and both E16B and $\mathrm{E} 16 \mathrm{C}$ clones at $96 \mathrm{hr}$ treated either without 4-OHT (upper panels) or with 4-OHT (lower panels).

data at 96 -hr. For the control clones, there is no change in cell viability whether or not 4-OHT is present. However, for the MERT clones, the cultures are $\sim 45-55 \%$ dead after $96 \mathrm{hr}$ treatment with 4-OHT, and this death is accompanied by DNA laddering, a hallmark of apoptosis

(Fig. 3B). Only the MERT clones induced with 4-OHT show any significant laddering (Fig. 3B; cf. E16B + and $\mathrm{E} 16 \mathrm{C}+$ lanes with all others); DNA from control clones and uninduced MERT clones is unaffected. Finally, examination of nuclear morphology by staining with the nonintercalating benzimidazole dye Hoechst 33258 demonstrated that after $96 \mathrm{hr}$ the nuclei of the MERTexpressing cells have a bright and irregular appearance when 4-OHT is present, but have normal rounded appearance when it is absent (Fig. 3C). The fragmented morphology of the nuclei suggests that the DNA is being degraded and nuclear collapse is occurring. Together, these data confirm that interfering with the activity of Myb proteins, at least in the EL4 cell line, causes apoptosis.

\section{Interfering with Myb activity enhances apoptosis during thymopoiesis}

We next wished to determine whether the apoptosis we observed in EL4 cells upon induction of the MERT allele was recapitulated in the thymocytes of our MT and MEnT transgenic mice. As described above (see the introduction), thymocyte development in these mice is inhibited. Animals heterozygous for either transgene have an essentially normal thymocyte subset profile, as assessed by staining with antibodies against CD4 and CD8, but total thymocyte numbers are reduced by between four- and eightfold relative to nontransgenic controls. Homozygotes are more severely affected, with a 20 -fold reduction in thymocyte numbers; a block to differentiation apparently occurs at an early point in thymopoiesis, the transition from $\mathrm{CD}^{-} \mathrm{CD} 8^{-}$(double negative, $\mathrm{DN}$ ) to $\mathrm{CD} 4{ }^{+} \mathrm{CD} 8{ }^{+}$(double positive, DP) cells (Badiani et al. 1994). Peripheral T cells from both heterozygotes and homozygotes are unable to proliferate efficiently in response to antigen stimulation in in vitro assays. From our observations in EL4 cells, it seemed possible that the phenotype of these animals might be attributable to an increase in the susceptibility of transgenic $T$ cells to apoptosis. We therefore assayed the fragility of thymocytes and splenic $T$ cells from nontransgenics, or from animals heterozygous for either the MT or MEnT transgene. Heterozygotes were chosen, because their thymocyte subset distribution is very similar to that of nontransgenics, enabling a direct comparison between transgenic and wild-type mice. Thymocytes and $\mathrm{T}$ cells were cultured under conditions known to mimic in vivo apoptotic stimuli: growth in simple tissue culture medium, growth in the presence of dexamethasone, and growth following X-irradiation. Results are shown in Figure 4A. When grown for $18 \mathrm{hr}$ without any treatment, an average of $\sim 10 \%$ of transgenic thymocytes and $\mathrm{T}$ cells were still alive, in contrast with around $40 \%$ of the thymocytes and $T$ cells of nontransgenic littermates. Treatment of cells with dexamethasone or X-rays resulted in almost complete death of transgenic cultures, whereas around $5-10 \%$ of cells in nontransgenic cultures survived. Therefore, transgenic cells from both lines of mice were 

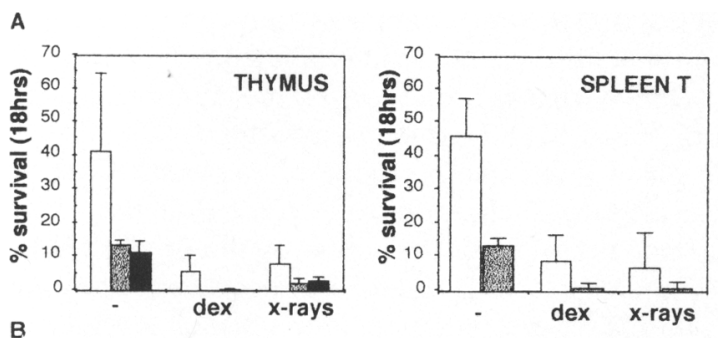

TUNEL

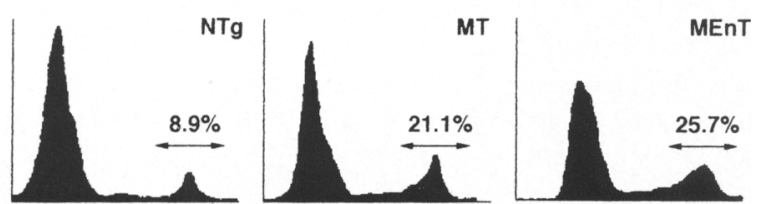

Figure 4. Thymocytes and $T$ cells of transgenic mice expressing a Myb dominant interfering allele have increased susceptibility to apoptotic stimuli. $|A|$ Survival in culture of nontransgenic (open bars), MT (gray bars), and MEnT (solid bars) thymocytes and splenocytes after no treatment, addition of $1 \mathrm{~mm}$ dexamethasone, or exposure to 225-rad X-rays. $(B)$ TUNEL assays on nontransgenic, MT, or MEnT thymocytes. Cells were cultured for $5 \mathrm{hr}$, stained, and assessed by flow cytometry. A representative experiment is shown.

at least four times more fragile than nontransgenic controls when exposed to apoptotic stimuli.

We looked for evidence of increased levels of apoptosis in the thymuses of transgenic animals from the MT and MEnT lines. Although thymic apoptosis is normally rather hard to discern because of efficient clearance of dead and dying cells, better detection is possible if cells are cultured for a short time before analysis (Kishimoto et al. 1995). Accordingly, thymocytes from 3-week-old mice were purified, cultured for $5 \mathrm{hr}$, labeled by TdTmediated dUTP-fluorescein end-labeling (TUNEL), and analyzed by flow cytometry. A representative experiment is shown in Figure 4B. When compared with a nontransgenic sibling, thymocytes from heterozygous animals from both transgenic lines show a higher percentage of apoptotic death, as measured by a 2.4-(MT) to 2.9-fold (MEnT) increase in the amount of TUNEL staining. In support of this, TUNEL staining of thymic sections from heterozygous MEnT animals also revealed more cell death in situ than was found in the thymuses of nontransgenic siblings (data not shown). These data show that thymocytes from Myb dominant interfering transgenic animals are dying in vivo in greater numbers than normal.

\section{Bcl-2 expression is repressed by induction of MERT}

Having shown that apoptosis in response to Myb shutoff occurs in mice as well as in a cell line, we were interested to discover whether genes known to control apoptosis were differentially regulated in the presence or absence of Myb dominant interfering proteins. For this experiment, we returned to the EL4-derived cell lines.
Cells from the two high MERT expressors E16B and E16C, as well as the MCl clone, were incubated with and without 4-OHT, and both RNA and protein extracts were harvested every $24 \mathrm{hr}$. Northern blots were probed for the bcl-2 family members $b c l-2, b a x, b a k$, and $b c l-x$. No changes were detected in levels of $b a x$ and $b c l-x$ mRNA, and bak expression was undetectable /data not shown). However, as shown in Figure 5A, bcl-2 mRNA is down-regulated as early as $24 \mathrm{hr}$ after $4-\mathrm{OHT}$ induction in both MERT clones; levels remain constant in control $\mathrm{MCl}$ cells with and without 4-OHT, and were also unchanged after $96 \mathrm{hr}$ with or without 4-OHT in the control RT and ERT lines (data not shown). The decrease seen in the MERT clones is recapitulated at the protein level, albeit with slower kinetics, as shown in the Western blot in Figure $5 \mathrm{~B}$; again levels of Bcl-2 protein in control MCl cells stay the same. The apparently slow

A

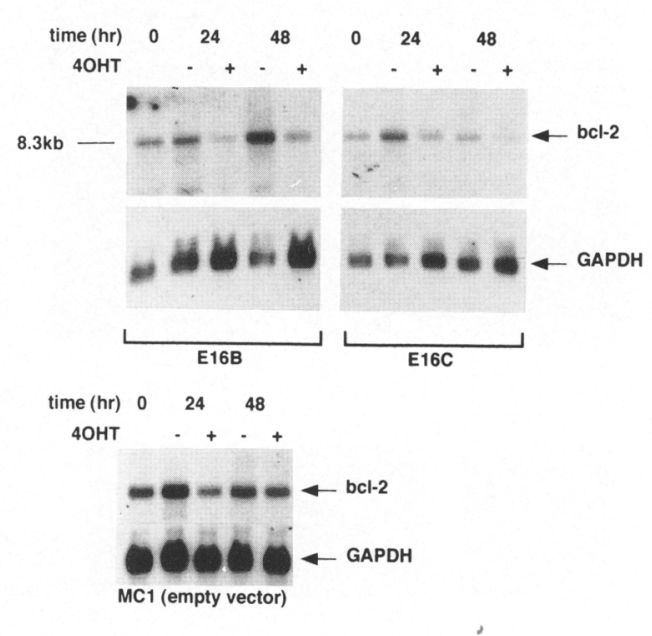

B

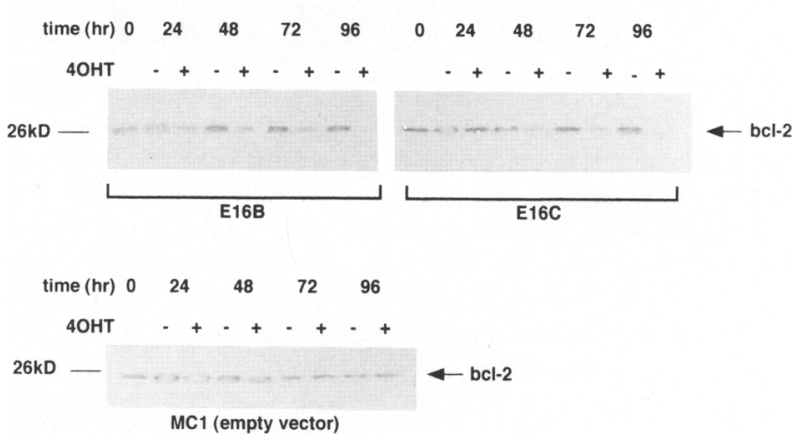

Figure 5. Down-regulation of $\mathrm{Bcl}-2$ expression correlates with induction of MERT. $(A)$ Northern blot of $20 \mu \mathrm{g}$ total cellular RNA harvested from E16B, E16C, and control MCl cells at 24-hr intervals \pm 4 -OHT, probed with bcl-2 (upper panels) and, as a loading control, GAPDH (lower panels). (B) Western blot of protein extracts taken from $10^{6}$ cells from $\mathrm{MCl}, \mathrm{El} 6 \mathrm{~B}$, and E16C clones every $24 \mathrm{hr} \pm 4-\mathrm{OHT}$ and probed with antimouse bcl-2 antibody. 
turnover of Bcl-2 protein in MERT cells correlates well with the 48- to 72 -hr lag in appearance of the apoptotic phenotype after 4-OHT induction.

\section{Expression of bcl-2 is associated with rescue of MERT or MEnT-induced apoptosis}

We wished to determine whether Bcl-2 could rescue cells expressing Myb dominant interfering proteins from apoptosis, both in the cloned cell lines and in our transgenic mice. For the cell lines, rather than simply overexpressing Bcl-2, we tested whether a Myb protein could override the effects of MERT induction and whether this correlated with a change in endogenous $b c l-2$ mRNA levels. The v-Myb oncoprotein was used for the rescue experiment, as it is a stronger transcription activator than its close relative c-Myb. Clone E16C was transfected stably with a vector constitutively expressing $\mathrm{v}-\mathrm{Myb}$, or a control empty vector, and doubly transfected clones were isolated. In comparison with the E16C parent clone, the clones transfected with empty vector alone were more susceptible to death when MERT was induced with 4-OHT, probably because double selection with G418 and puromycin had increased their sensitivity to apoptotic stimuli (Fig. 6A; cf. E16C with P1 and P7). However, clones V3 and V4, which constitutively express $\mathrm{v}-\mathrm{Myb}$, were partially protected from apoptosis when MERT was induced. After $96 \mathrm{hr}, 69 \%$ of control P1 and P7 cells were dead, in contrast to $31 \%$ (V4) and $41 \%$ (V3) of v-Myb expressing cells (Fig. 6A; cf. P1 and P7 with V3 and V4). Although levels had not returned to those seen in the absence of 4-OHT, significant rescue had occurred. Using RNAse protection mapping we exam- ined endogenous $b c l-2$ mRNA in the doubly transfected clones. As shown in Fig. 6B, control clone P1 showed a marked reduction in bcl-2 mRNA levels after $24 \mathrm{hr}$, and this was still the case $96 \mathrm{hr}$ after MERT induction, in good agreement with our previous data. However, when MERT was induced in the v-Myb expressors, V3 and V4 (Fig. 6B), the level of bcl-2 mRNA did not decrease, but instead remained similar to that seen in the absence of 4-OHT, even 72 and $96 \mathrm{hr}$ after induction. Therefore, $\mathrm{v}$-Myb can counteract the effects of MERT, and the decrease in apoptosis coincides with rescue of bcl-2 expression.

A number of transgenic mouse lines have been established in which Bcl-2 is overexpressed in the T cell lineage (Sentman et al. 1991; Strasser et al. 1991). Although T-cell homeostasis is not affected, transgenic thymocytes and splenocytes are extremely resistant to apoptosis under a number of conditions, both in vivo and in vitro. We crossed heterozygous MEnT mice with E $\mu b c l$ 2-25 mice (Strasser et al. 1991), which express Bcl-2 from early times in thymopoiesis. To assay for rescue of the MEnT phenotype, we initially counted the total number of thymocytes. In this experiment, MEnT animals had an average thymocyte count of $2.4 \times 10^{7}$, in contrast to normal or E $\mu b c l-2-25$ mice, whose thymuses contained on average $2.3 \times 10^{8}$ thymocytes. In double MEnT/ E $\mu b c l-2-25$ transgenics, numbers had increased to $5.8 \times 10^{7}$ indicating that introduction of the $b c l-2$ transgene had compensated partially for the effects of MEnT on thymocyte number. In a modification of the experiment shown in Figure 4B we also looked, using TUNEL, for a decrease in the proportion of apoptotic cells in double transgenic animals. Figure $6 \mathrm{C}$ shows that introduc-
A

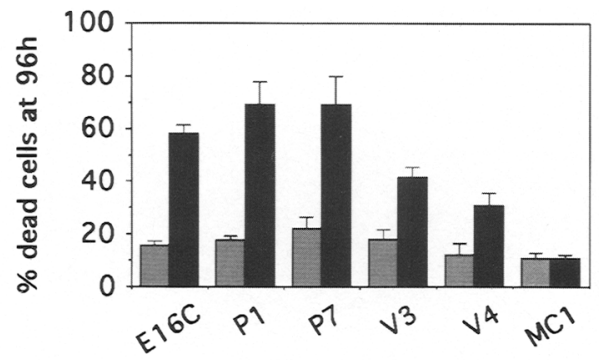

B

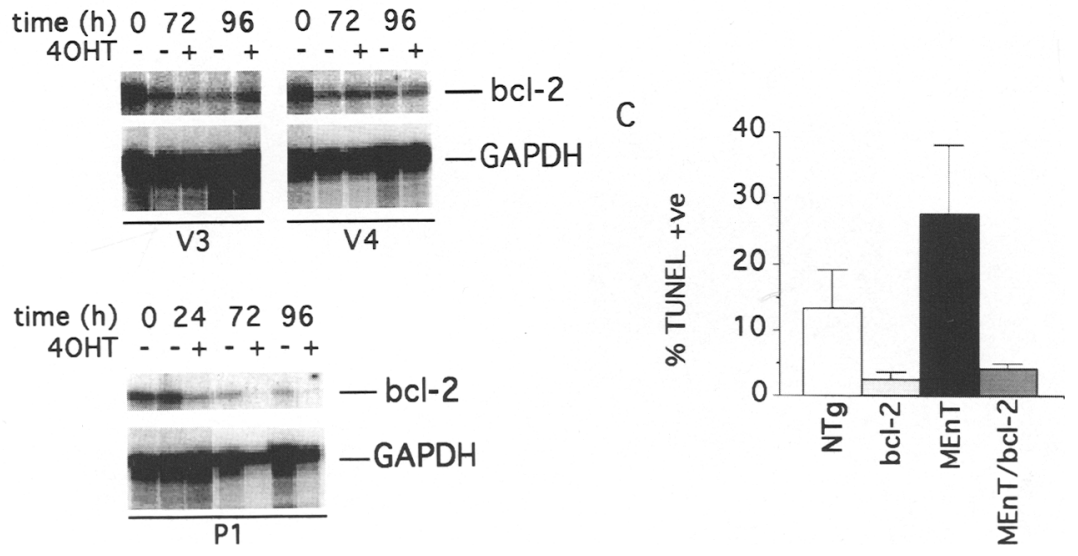

Figure 6. Expression of Bcl-2 rescues apoptosis induced by Myb dominant interfering proteins. $(A) \mathrm{Graph}$ of the percentage of dead cells in the E16C parent clone and the doubly transfected clones $\mathrm{Pl}$ and $\mathrm{P} 7$ (empty vector) and V3 and V4 (v-Myb expressors) at $96 \mathrm{hr}$, as counted by trypan blue inclusion, either when incubated without 4-OHT (gray bars) or with 4-OHT (solid bars). Clone $\mathrm{MCl}$ results from Fig. $3 \mathrm{~A}$ are shown for comparison. (B) RNAse protection mapping of $20 \mu \mathrm{g}$ total cellular RNA harvested from $v$-Myb expressing (V3 and $\mathrm{V} 4)$ and control cells (P1), grown either with $(+)$ or without $(-14-\mathrm{OHT}$, after the times indicated. Protected fragments correspond to $b c l-2$ mRNA (upper band) and GAPDH mRNA (lower band). (C) TUNEL assays on nontransgenic, MEnT and E $\mu b c l-2-25$ (bcl-2) transgenic, and MEnT/ Eubcl-2-25 (MEnT/bcl-2) double transgenic thymocytes. Cells were cultured for $5 \mathrm{hr}$, stained, and assessed by flow cytometry. The histogram depicts the means and standard deviations of results from two to five separate animals. 
ing the E $\mu \mathrm{bcl}-2-25$ transgene into our MEnT lines reduced the number of TUNEL positive thymocytes from an average of $27.7 \%$ to $4.0 \%$, a figure close to the $2.4 \%$ obtained using E $\mu b c l-2-25$ single transgenics. Taken together with the data obtained in cell lines, these results show that an increase in bcl-2 expression is associated with rescue of MEnT- or MERT-induced apoptosis and provide further evidence that Myb may be an upstream regulator of Bcl-2.

\section{$B c l-2$ is a direct target of $M y b$}

Having shown that down-regulation of Bcl-2 appears to be an important factor in MERT- and MEnT-induced apoptosis, we tested whether $b c l-2$ transcription was regulated directly by Myb. Using MERT clone E16C, we assessed the speed with which $b c l-2$ transcription was inhibited after induction of MERT, by performing nuclear run-on assays. Cells were incubated with or without 4-OHT and nuclei were harvested at 0 and $2 \mathrm{hr}$ after induction. Radiolabeled nascent RNA transcripts were hybridized to $b c l-2$ sense and antisense DNA /schematised in Fig. 7A) bound to nitrocellulose filters. Results are shown in Figure 7B. Two hours after incubation with 4-OHT, $b c l-2$ sense transcription was reproducibly reduced by half, indicating that inhibition of Myb activity causes a rapid shutdown of $b c l-2$ transcription. As observed previously for the human $b c l-2$ gene (Young and Korsmeyer 1993), there was some hybridization of an- tisense RNA, which was more apparent under conditions where sense strand transcription was elevated.

The $b c l-2$ gene has two promoters, $\mathrm{P} 1$ and $\mathrm{P} 2$, which are $1.5 \mathrm{~kb}$ and $200 \mathrm{bp}$, respectively, upstream of the initiating ATG. The P2 promoter is rarely used (Young and Korsmeyer 1993). We searched the sequence of the $2-\mathrm{kb}$ region containing these promoters and found one perfect match, CAACGG, to the Myb binding consensus (Fig. 7A). As shown in Figure 7C, a labeled oligonucleotide containing this site and its surrounding sequence forms a complex in a bandshift assay with reticulocyte lysate programmed to express Myb protein (lane 1), but does not recognize any bands in unprogrammed lysate (lane 5). This complex contains Myb, as it can be abolished with a 50-fold molar excess of a cold oligonucleotide carrying a high affinity Myb binding site, mimA (lane 2; Ness et al. 1989), but not with excess cold mutant mimA (lane 3). An identical probe in which the myb site is mutated to CCACGG is unable to bind Myb (bcl-2M; lane 4). To test the importance of this Myb binding site for transcription of the $b c l-2$ gene, we constructed a luciferase reporter vector, in which luciferase transcription was driven by a 450-bp fragment of $b c l-25^{\prime}$ sequence (Fig. 7A) containing the $\mathrm{P} 2$ promoter. We transfected this reporter construct into EL4 cells, and found that the bcl-2 promoter fragment reproducibly activated expression of the luciferase gene to an average level of 5.3-fold over baseline (Fig. 7D). In contrast, when the Myb consensus was mutated from CAACGG to CCACGG, mak-
Figure 7. Direct regulation of bcl-2 by myb. (A) The murine $b c l-2$ promoter. (Shaded boxes) Introns. The P1 and P2 promoters and the myb binding site are indicated. Sense and antisense DNA probes and the $b c l-2$ promoter fragment used for luciferase assays are also shown. $(B) \mathrm{Nu}-$ clear run-on assays using nuclei from E16C cells harvested prior to induction with 4-OHT $(t=0)$ and after 2-hr treatment \pm 4 -OHT. Labeled RNA transcripts were hybridized to the sense and antisense $b c l-2$ probes shown above (both in an M13 vector background) with M13 ssDNA and GAPDH as controls. "Sense" and "antisense" refer to the detected $b c l-2$ transcripts. $(C)$ Myb protein can bind the $b c l-2$ promoter. (Lanes 1-3) bcl-2 probe; (lane 4) bcl-2M probe. Lanes 1-4 contain MT-programmed lysate, and lane 5 blank lysate; $100 \mathrm{ng}$ cold competitor oligonucleotide was added where shown. Free probe is shown at a shorter exposure, as otherwise the retarded complex is obscured. $(D) \mathrm{Lu}-$ ciferase assays of the $b c l-2$ promoter in EL4 cells. Luciferase activity is shown in the actual units derived from scintillation counting. Assays were performed in duplicate; the average and standard deviation of
A

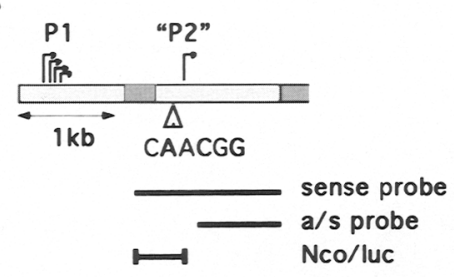

C

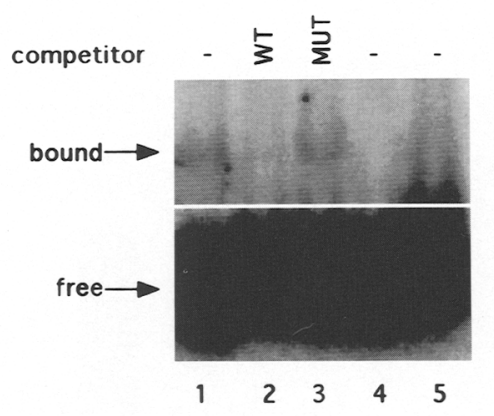

B

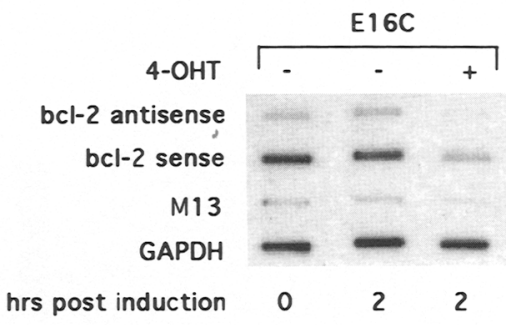

D

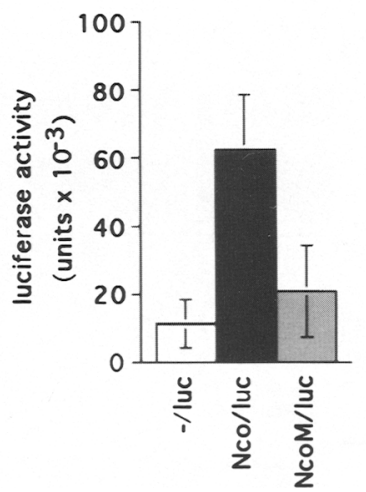


ing it unable to bind Myb protein, we saw a marked decrease in luciferase activity to an average level of 1.8fold over baseline (Fig. 7D). Similar effects were observed when the luciferase reporter was driven by a $4.5-\mathrm{kb}$ fragment of bcl-2 5' sequence containing both P1 and P2 promoters; mutation of the Myb consensus resulted in the loss of half of the activity of the promoter (data not shown). Taken together, these data show that the Myb consensus in the bcl-2 promoter is a bona fide Myb binding site, and that this site is an important positive regulatory element in EL4 cells.

\section{Discussion}

We have stably expressed an inducible dominant interfering Myb mutant, MERT, in the murine thymoma line EL4. Between 48 and $72 \mathrm{hr}$ after induction, a significant number of cells begin to apoptose, as assessed by cell counts, nuclear morphology, and DNA fragmentation. In transgenic mice expressing similar dominant interfering Myb proteins in their T-cell lineages, transgenic thymocytes and $T$ cells are more responsive to apoptotic triggers, such as dexamethasone and X-rays. The mice also show increased apoptosis during thymopoiesis, as detected by TUNEL staining. In EL4 cells, induction of apoptosis is correlated with down-regulation of $b c l-2 \mathrm{ex}-$ pression; only low levels of bcl-2 mRNA remain $24 \mathrm{hr}$ after induction, and bcl-2 protein is also switched off, although with slower kinetics. Expression of exogenous $\mathrm{v}$-Myb partially rescues cells from both down-regulation of $\mathrm{Bcl}-2$ and apoptosis; furthermore, $\mathrm{Bcl}-2$ expression in the dominant interfering transgenic lines also rescues thymocytes from cell death. Run-on assays and analysis of the $b c l-2$ promoter suggest strongly that down-regulation may be attributable to Myb regulating bcl-2 transcription directly.

\section{Are Myb proteins survival factors?}

It is formally possible that the apoptosis caused by our dominant interfering alleles is not an indicator that wildtype Myb proteins have antiapoptotic functions, but is induced as a consequence of the inability of the cells to grow properly in the absence of Myb activity. We do not consider this likely for a number of reasons: First, Myb proteins are clearly not essential for the growth and differentiation of many cell types both inside and outside the hemopoietic system (e.g., see Mucenski et al. 1991); second, the direct regulation by Myb of the survival gene $b c l-2$ characterizes Myb as an upstream component of a well-established antiapoptotic pathway; third, we and others have shown that overexpression of Myb proteins can protect cells against apoptosis (Smarda and Lipsick 1994; Bies et al. 1996; P. Badiani and K. Weston, unpubl.). Taken together, these data argue strongly that Myb proteins have an important regulatory role in the response of certain cell types to apoptotic stimuli.

The apoptosis observed in EL4 cells on MERT induction is mediated via the Myb DNA binding domain, because control proteins lacking this region are inert. How- ever, MERT can potentially interfere with the activity of A-, B-, and c-Myb, which all recognize the same binding site. Although A-Myb is not expressed during murine thymopoiesis (Mettus et al. 1994; Sitzmann et al. 1995), the target genes down-regulated by MERT binding may be regulated by B- or c-Myb, or both. B-myb is expressed in EL4 cells, although at a lower level than c-myb (data not shown), and in vivo, the expression patterns of B- and c-myb overlap during T-cell development and activation (Stern and Smith 1986; Golay et al. 1991). Current data suggest that B-Myb appears to fulfill a biologically similar role to $\mathrm{c}-\mathrm{Myb}$, inhibiting growth when it is absent, and stimulating proliferation when it is deregulated (Lin et al. 1992; Sala and Calabretta 1992). However, further experiments are required to determine whether c- and B-Myb share the ability to protect $\mathrm{T}$ cells from apoptosis.

\section{Myb, apoptosis, and the cell cycle}

We have shown here that inhibition of Myb activity reduces the apparent growth of EL4 cells and that this is due to apoptosis. Additionally, we found that the thymocytes and splenocytes of mice transgenic for Myb dominant interfering mutants have decreased survival in culture and are more sensitive to apoptotic triggers, and that all stages of T-cell maturity are more prone to apoptosis. In our experiments in EL4 cells, MERT induction had little or no effect on cell-cycle control; relative numbers of cells in each stage of the cell cycle remained the same, and they were cycling normally. These data are contrary to previous reports implicating Myb proteins as regulators of the $G_{1} / S$ transition of the cell cycle (see the introduction). As it might be expected that a transformed cell line such as EL4 might have accumulated mutations resulting in a deregulated cell cycle, we do not exclude the possibility that Myb may have a dual function in preventing cell death and regulating cell growth. In support of this notion, forced expression of both $c$ - and B-Myb has been reported to enhance TGF- $\beta$-induced apoptosis in M1 cells (Selvakumaran et al. 1994; Bies and Wolff 1995), but to maintain proliferation and protect these cells against IL-6-induced death and differentiation (Bies et al. 1996). Intriguingly, in this paper we were able to rescue MEnT transgenic thymocytes from stress-induced apoptosis with a bcl-2 transgene, but total thymocyte numbers did not return to wild-type levels, suggesting that inhibition of Myb might affect either other survival genes (see below) or perhaps other cellular processes, such as the cell cycle.

\section{Myb and the bcl-2 family}

We have shown that apoptosis in response to MERT induction in EL4 cells is temporally linked to down-regulation of the bcl-2 gene, a fundamental component of survival pathways in many cell types, including $\mathrm{T}$ cells (Craig 1995). Little is known about transcriptional regulation of $b c l-2$. Most transcripts originate from the distal 
P1 promoter, which has no detectable TATA or CAAT boxes, but has GC-rich regions containing multiple Spl binding sites and start sites; the proximal P2 promoter is apparently almost inactive. Although no detailed studies of the $b c l-2$ promoter have been undertaken in $\mathrm{T}$ cells, analysis of the upstream region of the human $b c l-2$ gene in a number of B-cell lines has shown that the region between the P1 and P2 promoters, highly conserved between mouse and man, contains a number of DNase hypersensitive sites and a negative regulatory element (Young and Korsmeyer 1993); the region $5^{\prime}$ to the P1 promoter is also DNase hypersensitive and contains negative elements (Young and Korsmeyer 1993; Chen and Boxer 1995). Our data suggest that Myb proteins are direct regulators of $b c l-2$, binding to a site in the conserved regulatory region flanked by the $\mathrm{P} 1$ and $\mathrm{P} 2$ promoters. The apoptosis caused by induction of MERT correlates with a rapid decrease in $b c l-2$ transcription, and mutation of the Myb site in the $b c l-2$ promoter greatly reduces its activity in EL4 cells, implying that the factor binding there, presumably a Myb protein, is important for $b c l-2$ transcription. In support of this conclusion, J. Frampton, T. Ramqvist, and T. Graf (in prep.) have observed a similar regulation of $b c l-2$ by chicken Myb-Ets in transformed avian myeloblasts; they also show that v-Myb can bind to and activate transcription from Myb binding sites in the chicken and human $b c l-2$ promoters.

Transcriptional activation of $b c l-2$ by Myb proteins requires that the expression patterns of the genes coincide. B-myb mRNA is detected in thymus and spleen (Golay et al. 1991; Tashiro et al. 1995), but more detailed expression studies have not been performed. c-myb, like bcl-2, is expressed at high levels in hemopoietic stem cells in the bone marrow (Hockenbery et al. 1991; Orlic et al. 1995). Detailed analysis of the subset-specific expression of Myb proteins in the thymus has not been undertaken, but the highest levels of $\mathrm{c}-m y b$ are found in immature cortical thymocytes, which may be either DN or DP (Sheiness and Gardinier 1984). bcl-2 is expressed in DN thymocytes, is down-regulated as cells become DP and undergo selection, but is then up-regulated in positively selected DP cells (Linette et al. 1994). After the DP stage, $b c l-2$ mRNA is found in medullary thymocytes (Veis et al. 1993), and is also present in peripheral resting T cells; c-myb is not expressed in either of these populations. However, both $b c l-2$ and c-myb are up-regulated upon antigenic stimulation (Stern and Smith 1986; Veis et al. 1993). Therefore, there are stages of T-cell development where both $b c l-2$ and c-myb are expressed, making the regulation of one by the other feasible. Interestingly, the late DN stage and peripheral $\mathrm{T}$-cell activation are both points at which there is a sustained burst of proliferation. Perhaps c-Myb is the regulatory factor that maintains $b c l-2$ expression at these times, thereby preventing death by neglect, which can occur when growth factor levels cannot meet the demands of a rapidly expanding population.

A second $b c l-2$ family member, $b c l-\mathrm{x}_{\mathrm{L}}$ is important during murine T-cell development (Gonzalez Garcia et al. 1995). $b c l-\mathrm{x}_{\mathrm{L}}$ is expressed at high levels in the bone marrow, in DP thymocytes, and activated peripheral T lymphocytes (Fang et al. 1994). It is absent from DN and SP thymocytes and resting mature $T$ cells, places where $b c l-2$ is expressed, implying that these genes are regulated differentially. Although we observe no change in levels of $b c l$-x mRNA in response to MERT induction in EL4 cells, we are investigating the possibility that, in vivo, Myb may be involved in regulating $b c l-x_{\mathrm{L}}$ in specific thymocyte subsets for which EL4 cells may not be representative.

\section{Other potential Myb-regulated targets in apoptosis}

Down-regulation of $b c l-2$ expression may not be wholly responsible for the induction of apoptosis caused by Myb dominant interfering proteins, because increasing $b c l-2$ expression achieved only partial rescue of the apoptotic phenotype. c-Myb has been proposed to regulate three other genes with known roles in apoptosis. The first, c-myc, has multiple Myb consensus sequences in its promoter (Nakagoshi et al. 1992), but these are not required for activation by c-Myb (Graf 1992), and the biological relevance of the interaction remains unclear. This target cannot account for the effects we see when Myb activity is ablated in EL4 cells because we do not detect any changes in endogenous c-myc mRNA levels when MERT is induced (data not shown). Up-regulation of c-Myc by c-Myb might also be expected to induce apoptosis (Evan et al. 1992) rather than protect against it, and so we do not consider it to be a likely downstream effector of c-Myb in this context. The two other genes, IGF-1 and the IGF-1 receptor (Reiss et al. 1991), have been shown to be involved in rescue from Myc-induced death (Harrington et al. 1994); we have found that addition of exogenous IGF-1 partially rescues the apoptotic phenotype caused by induction of MERT in the EL4 cells (data not shown), making it possible that $\mathrm{Myb}$ is required to maintain the expression of this survival factor.

T cell-mediated cytotoxicity is partially attributable to the interaction between a cell surface molecule, Fas, and its ligand, FasL; this interaction kills target cells and also eliminates activated $\mathrm{T}$ cells by induction of apoptosis (Nagata and Golstein 1995). When Fas or FasL are absent or mutated, as in the lpr and gld mouse mutants, a population of almost inert $\mathrm{T}$ cells builds up, which are resistant to Fas-mediated modes of cell death. This resistance is augmented markedly by introduction of a $b c l-2$ transgene (Strasser et al. 1995), implying that Bcl-2 and Fas regulate distinct pathways to lymphocyte apoptosis. These data are particularly relevant to our studies, as levels of c-myb mRNA are strikingly high in lpr and gld $T$ cells (Mountz et al. 1984), and therefore endogenous Bcl-2 might be expected to be similarly abundant. Possibly, in lpr cells, the level of a Bax family member is also high, and so Bcl-2 is inactivated. We intend to investigate whether $\mathrm{c}-\mathrm{Myb}$ is playing a protective role in $1 p r$ and gld $\mathrm{T}$ cells and, if so, whether it is by a Bcl-2 dependent or independent mechanism. Interestingly, we detect an up-regulation of Fas in the MERT clones in the presence of 4-OHT (data not shown). 


\section{$c-M y b$ and cancer}

The notion that Myb proteins may act as antiapoptotic factors has implications for the role of $\mathrm{c}-\mathrm{Myb}$ in oncogenesis. v-Myb causes rapid-onset myeloid and B lymphocytic tumors in mice and chickens (Weston 1990). Presumably these tumors arise through some other mechanism than aberrant protection from apoptosis, as such tumors would be expected to be fairly indolent, like the follicular lymphomas associated with $b c l-2$ deregulation via the $t(14 ; 18)$ translocation (Korsmeyer 1992). Nevertheless, a role for c-Myb as a survival factor in the maintenance of these and other tumors, including human cancers, is possible. A frequent chromosomal abnormality in acute lymphoblastic leukemias (ALLs) and non-Hodgkins lymphomas (NHLs) is a 6q- deletion (Bloomfield et al. 1983), close to the c-Myb locus at 6q23.3-6q24. Although rearrangement of $\mathrm{c}-\mathrm{Myb}$ has been detected in only a few human tumors (Alitalo et al. 1984; Pelicci et al. 1984), significant up-regulation of transcription occurs in many cases (Barletta et al. 1987; Ohyashiki et al. 1988; Tesch et al. 1992). Combining these data and our results, it is feasible that overexpression of c-Myb may protect an abnormal cell from apoptosis, thereby allowing it to accumulate other mutations resulting in full-blown malignancy. We are currently investigating this possibility and also are examining the correlation between c-myb and $b c l-2$ expression in tumor cell lines.

In summary, then, we have shown a new biological role for Myb proteins, as protective factors against apoptosis during thymopoiesis and T-cell growth. Further, we have established a link between $\mathrm{Myb}$ and $\mathrm{Bcl}-2$, and have presented evidence that the $b c l-2$ promoter is a direct target of Myb. In the light of these data, a reevaluation of the wider role of Myb proteins during hemopoiesis seems necessary; as hemopoietic cells must choose between self-renewal, differentiation, or death at all stages of their development, it seems feasible to suggest that the antiapoptotic function of the Myb proteins might be vital to these decisions. Future experiments will be directed toward resolving this issue.

\section{Materials and methods}

\section{Plasmid construction}

Plasmid DNA manipulations and preparations were by standard methods. All constructs were checked by restriction mapping, and in-frame fusions and PCR products were verified by doublestranded sequencing by standard techniques. Details of plasmid constructions are available on request.

ER HBD fusion proteins MERT: A fragment comprising nucleotides 841-1797 (amino acids 281-599) of the murine estrogen receptor was generated by PCR from pBSKSMER/G525R (Littlewood et al. 1995) and inserted into pT7ßMEnT (Badiani et al. 1994) $5^{\prime}$ to the myc 9E10 epitope tag. Then the MERT fusion gene was excised from pT7 $\beta M E R T$ and ligated into pMCEF $^{-}$ (R. Marais, unpubl.), a modified expression vector derived from pMClneo (Stratagene) that uses the strong EF-la promoter to drive high levels of expression of the inserted genes. ERT:
The 2-kb ERT fragment of $\mathrm{pMCEF}^{-}$MERT was inserted into $\mathrm{pMCEF}^{-}$to generate $\mathrm{pMCEF}^{-} \mathrm{ERT}$. RT: A pT7 $\beta M$ MT construct was made by inserting the ER HBD fragment $5^{\prime}$ of the myc tag of pT7ßMT (Badiani et al. 1994). The MRT fusion gene was excised and inserted into $\mathrm{pMCEF}^{-}$. The $1-\mathrm{kb}$ RT portion was excised and inserted into $\mathrm{pMCEF}^{-}$to generate $\mathrm{pMCEF}^{-} \mathrm{RT}$. Plasmids pSCDMEnT, $5 \mathrm{mim} / \mathrm{CAT}$, and IE $\beta$ gal are described in Badiani et al. (1994), and pMTV in Weston and Bishop (1989).

Luciferase reporter gene constructs $5 \mathrm{mim} / \mathrm{SV} / \mathrm{luc}$ : Five copies of the mimA site (Ness et al. 1989) were cloned upstream of the SV40 enhancer and a minimal tk promoter in pGL2Basic (Promega). Nco/luc was made by inserting the 450-bp NcoI$K p n I$ fragment of $b c l-2$ genomic DNA (Negrini et al. 1987) into pGL2Basic. NcoM/luc was identical except for a 1-bp change in the Myb consensus binding site at position 1632 /CAACGG to CCACGG|, introduced by PCR mutagenesis.

Run-on assays A 1.47-kb BamHI fragment spanning the murine $b c l-2$ P2 promoter region (nucleotides 910-2375; Negrini et al. 1987) was cloned into Phagescript SK (Stratagene) such that single-stranded phage carried the sense orientation. For the antisense orientation, an 815-bp HindIII-BamHI fragment (nucleotides $1560-2375$ ) was cloned in the opposite orientation in the same vector.

\section{Cell culture}

NIH-3T3 cells were grown at $37^{\circ} \mathrm{C}, 10 \% \mathrm{CO}_{2}$ in Dulbecco's Modified Eagle's Medium (Gibco) supplemented with $10 \%$ fetal calf serum (FCS) (Gibco). EL4 cells were maintained at $37^{\circ} \mathrm{C}, 5 \%$ $\mathrm{CO}_{2}$ in Iscove's Modified Dulbecco's Medium (Gibco) and $8 \%$ FCS. Stable transfectants of EL4 cells were produced by electroporation using a BioRad Gene Pulser and were selected with 750

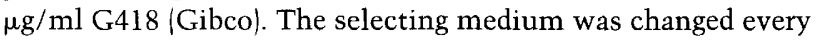
2 days, and colonies that were resistant to G418 were picked and cloned by limiting dilution. Doubly selected cells were selected and maintained in G418 and $4 \mu \mathrm{g} / \mathrm{ml}$ puromycin (Sigma).

To induce the ER HBD fusion proteins, the cells were incubated with $10^{-7} \mathrm{M} 4-\mathrm{OHT}$ (gift of M. Parker) or $10^{-6} \mathrm{M} 4-\mathrm{OHT}$ (Semat Technical UK Ltd.) at a starting density of $1 \times 10^{5} / \mathrm{ml}$. For time course counting analyses, samples were taken at times indicated, washed once in PBS, and counted by trypan blue exclusion. Experiments were repeated a minimum of five times, and histograms show the mean values and standard deviations. Northern and Western time course studies were performed in the same way (starting density of $1 \times 10^{5} / \mathrm{ml}$ ), taking samples $\left(2 \times 10^{6}\right.$ cells for RNA or $1 \times 10^{6}$ cells for protein) every $24 \mathrm{hr}$.

\section{Transient expression assays}

NIH-3T3 Assays used lipofectAMINE (Gibco), and conditions were optimized according to the manufacturer's instructions; $1.25 \times 10^{5}$ cells were seeded in each well of a six-well plate 18 hr before lipofection; $0.5 \mu \mathrm{g}$ DNA total was used per well. For CAT assays, extracts were taken $48 \mathrm{hr}$ post-lipofection by three cycles of freeze-thawing in $0.25 \mathrm{M}$ Tris- $\mathrm{HCl}$ at $\mathrm{pH} 7.5$ followed by centrifugation and were assayed for $\mathrm{CAT}$ and $\beta$-galactosidase activity as described previously (Badiani et al. 1994). Experiments were repeated three times.

EL4 For luciferase assays, $20 \mu \mathrm{g}$ of luciferase reporter was electroporated into EL4 cells together with $5 \mu \mathrm{g}$ IEßgal. Cells were 


\section{Taylor et al.}

harvested $24 \mathrm{hr}$ postelectroporation, washed once in PBS, and then lysed in cell culture lysis reagent (Promega). Luciferase assays were performed using the Luciferase Assay System (Promega) according to manufacturer's instructions and standardized by levels of $\beta$-galactosidase expression. Assays were repeated a minimum of three times in duplicate.

\section{RNA and protein analysis}

For the preparation of RNA samples, at least $2 \times 10^{6}$ cells were lysed in RNAzol B according to the manufacturer's protocol; 20 $\mu \mathrm{g}$ RNA was loaded per lane for Northern analysis. For $b c l-2$ expression, a full-length murine $b c l-2$ cDNA fragment was labeled by hexanucleotide priming. Blots were stripped and reprobed with a labeled DNA fragment hybridizing to murine GAPDH as a loading control. For RNAse protection mapping, $20 \mu \mathrm{g}$ total RNA was hybridized by standard methods to cRNA probes against $b c l-2$ and GAPDH mRNA and was digested with 10 units RNAse ONE (Promega) according to the manufacturer's instructions. Digested products were visualized by PAGE and autoradiography. For the bcl-2 probe, nucleotides 21652374 of murine $b c l-2$ genomic DNA were cloned into pT7 $\beta$ Sal (Badiani et al. 1994), such that the SP6 promoter was proximal to nucleotide 2374 . For the GAPDH probe: the $5^{\prime}$-most $250 \mathrm{bp}$ of murine GAPDH cDNA were cloned into pGEM2. Vectors were cut with $P_{V u I I}$ and Bstell, respectively, and radiolabeled cRNA probes were generated by SP6 transcription as described (Melton et al. 1984). The bcl-2 probe is 237 nucleotides long, and protects 209 nucleotides. The GAPDH probe is 160 nucleotides long and protects 153 nucleotides.

Protein extracts for Western blotting were made by standard methods, using $1 \times 10^{6}$ cells per sample. Samples were run on a $12 \%$ SDS polyacrylamide gel. Bcl-2 protein was detected using an antibody to amino acids 41-54, DHA7 (kind gift of Gerard Evan), a second-layer peroxidase-conjugated goat antirabbit immunoglobulin antibody (DAKO), and ECL reagents (Amersham|. MERT, ERT, and RT fusion proteins were detected using monoclonal antibody 9E10 (Evan et al. 1985).

\section{Bandshift assays}

Reticulocyte lysate programmed with pT7 $\beta M T$ to express the murine c-Myb DNA binding domain was prepared as described (Badiani et al. 1994). Double-stranded oligonucleotide probes were made by end-repair in the presence of $\left[\alpha{ }^{32} \mathrm{P}\right] \mathrm{dCTP}$. The bcl-2 probe is CTCATGCCAACGGGGAAACACCAGAA (nucleotides 1625-1650; Negrini et al. 1987), and the bcl-2M probe has CAACGG changed to CCACGG (myb site and mutated myb site underlined). WT cold competitor is the mimA site (Ness et al. 1989) CTAGGACATTATAACGGTTTTTTAGTCTAG; mutant cold competitor has TAACGG changed to TCACGG; bandshifts were performed as described (Krieg et al. 1995), except that the bcl-2 and bcl-2M probes were used at $\sim 2 \mathrm{ng}$ per reaction.

\section{Cell-cycle analysis}

We collected $10^{6}$ cells at each time point and washed them once in PBS. The cells were then fixed in $1 \mathrm{ml}$ ice-cold $70 \%$ ethanol/ $30 \%$ PBS for at least $30 \mathrm{~min}$ at $4^{\circ} \mathrm{C}$. Cells were centrifuged and resuspended in $1 \mathrm{ml}$ PBS containing $40 \mu \mathrm{g} / \mathrm{ml}$ propidium iodide and $2 \mu \mathrm{g} / \mathrm{ml}$ RNAse A. After incubation at $37^{\circ} \mathrm{C}$ for $30 \mathrm{~min}$, cells were analyzed on a Becton Dickinson FACScan. Data were processed using LYSYS II software.

\section{Apoptosis studies}

For Hoechst 33258 staining, cells were fixed in $70 \%$ ethanol/ $30 \% \mathrm{PBS}$ as above, then centrifuged and resuspended in $1 \mathrm{mg} /$ $\mathrm{ml}$ Hoechst 33258. Following incubation in the dark for $15 \mathrm{~min}$ at $4^{\circ} \mathrm{C}$, cells were examined under a fluorescence microscope. Apoptotic DNA fragments were isolated as described (Herrmann et al. 1994).

\section{Mice}

The derivation of the MEnT and MT transgenic mice has been described (Badiani et al. 1994). E $\mu b c l-2-25$ mice (Strasser et al. 1990 ) were a kind gift of Suzanne Cory. Thymocytes and splenocytes were prepared from 3- to 4-week-old mice by standard methods (Coligan et al. 1991). For survival assays, purified thymocytes and splenocytes were resuspended at $5 \times 10^{6}$ cells $/ \mathrm{ml}$ in RPMI supplemented with $5 \%$ heat-inactivated FCS and either treated with 225 rads X-rays, $1 \mathrm{~mm}$ dexamethasone, or nothing. Cells were cultured for $18 \mathrm{hr}$ in $5 \% \mathrm{CO}_{2}$ at $37^{\circ} \mathrm{C}$, harvested, and counted by trypan blue exclusion. Experiments were performed in triplicate, and histograms depict the mean and standard deviations of a minimum of three separate experiments. For TUNEL assays, thymocytes were purified and resuspended at $2.5 \times 10^{6}$ cells $/ \mathrm{ml}$ in RPMI containing $10 \%$ FCS and $5 \times 10^{-5} \mathrm{M} 2$-mercaptoetháiol. After $5 \mathrm{hr}$ in culture, TUNEL assays were performed using an in situ cell death detection kit (Boehringer) according to the manufacturer's instructions. Cells were analyzed on a Becton Dickinson FACScan using LYSYS II software. TUNEL assays were performed on at least four 3-week-old animals from each transgenic line, together with four nontransgenic age-matched controls. Assays on MEnT/bcl-2 double transgenics were performed twice.

\section{Nuclear run-on assays}

RNA isolation and transcript labeling were performed as described in Roberts and Bentley (1992). Hybridizations were carried out for $36 \mathrm{hr}$ at $65^{\circ} \mathrm{C}$ in $1 \mathrm{ml} 10 \mathrm{mM}$ Tris at $\mathrm{pH} 7.5,250$ $\mathrm{mg} / \mathrm{ml}$ RNA, $0.02 \%$ BSA, Ficoll 400, PVP360, 0.5\% nonfat dry milk, $0.3 \mathrm{M} \mathrm{NaCl}, 1 \%$ SDS, $10 \mathrm{~mm}$ EDTA, using $1 \times 10^{7} \mathrm{cpm}$ of labeled RNA. Filters were washed for $30 \mathrm{~min}$ at $65^{\circ} \mathrm{C}$ in $2 \times \mathrm{SSC}, 0.1 \%$ SDS, and for another $30 \mathrm{~min}$ at $65^{\circ} \mathrm{C}$ in $0.2 \times \mathrm{SSC}, 0.1 \%$ SDS. Filters were then treated with $10 \mathrm{mg} / \mathrm{ml}$ RNAse $A$ in $0.3 \mathrm{M} \mathrm{NaCl}, 10 \mathrm{~mm}$ Tris at $\mathrm{pH} 7.5,5 \mathrm{~mm}$ EDTA at $37^{\circ} \mathrm{C}$ for $30 \mathrm{~min}$, and washed for $15 \mathrm{~min}$ at $65^{\circ} \mathrm{C}$ in $1 \times \mathrm{SSC}$ prior to autoradiography. The experiment was performed four times.

\section{Acknowledgments}

We thank Prof Y. Tsujimoto for the murine $b c l-2$ genomic clone, Dr. A. Harris and Prof. S. Cory for E $\mu b c l-2-25$ mice, Dr. R. Marais for pMCEF, and Doreen Cantrell for transfectable EL4 cells. Jacqueline Marvel, Isla Furlong, Rose Zamoyska, and Richard Treisman were founts of useful advice, and Thomas Graf and Jon Frampton generously shared unpublished data. Finally, we are indebted to Professor Gerard Evan for probes, antibodies, much invaluable help and discussion, and providing the mutant estrogen receptor hormone binding domain prior to publication. This work is supported by the Cancer Research Campaign.

The publication costs of this article were defrayed in part by payment of page charges. This article must therefore be hereby marked "advertisement" in accordance with 18 USC section 1734 solely to indicate this fact. 


\section{References}

Alitalo, K., R. Winqvist, C.C. Lin, A. de la Chapelle, M. Schwab, and J.M. Bishop. 1984. Aberrant expression of an amplified c-myb oncogene in two cell lines from a colon carcinoma. Proc. Natl. Acad. Sci. 81: 4534-4538.

Arsura, M., M. Introna, F. Passerini, A. Mantovani, and J. Golay. 1992. B-myb antisense oligonucleotides inhibit proliferation of human hematopoietic cell lines. Blood 79: 2708-2716.

Badiani, P., P. Corbella, D. Kioussis, J. Marvel, and K. Weston. 1994. Dominant interfering alleles define a role for c-Myb in T cell development. Genes \& Dev. 8: 770-782.

Barletta, C., P.-G. Pelicci, L.C. Kenyon, S.D. Smith, and R. Dalla-Favera. 1987. Relationship between the c-myb locus and the 6q- chromosomal aberration in leukemias and lymphomas. Science 235: 1064-1067.

Bies, J. and L. Wolff. 1995. Acceleration of apoptosis in transforming growth factor beta 1-treated M1 cells ectopically expressing B-myb. Cancer Res. 55: 501-504.

Bies, J., B. Hoffman, A. Amanullah, T. Giese, and L. Wolff. 1996. B-Myb prevents growth arrest associated with terminal differentiation of monocytic cells. Oncogene 12: 355-363.

Bloomfield, C.D., D.C. Arthur, G. Frizzera, E.G. Levine, B.A. Peterson, and K.J. Gajl-Peczalska. 1983. Nonrandom chromosome abnormalities in lymphoma. Cancer Res. 43: 29752984.

Burgess, T.L., E.F. Fisher, S.L. Ross, J.V. Bready, Y.X. Qian, L.A. Bayewitch, A.M. Cohen, C.J. Herrera, S.S. Hu, T.B. Kramer, F.D. Lott, F.H. Martin, G.F. Pierce, L. Simonet, and C.L. Farrell. 1995. The antiproliferative activity of $\mathrm{c}-\mathrm{myb}$ and c-myc antisense oligonucleotides in smooth muscle cells is caused by a nonantisense mechanism. Proc. Natl. Acad. Sci. 92: 4051-4055.

Calabretta, B. 1991. Inhibition of protooncogene expression by antisense oligodeoxynucleotides: Biological and therapeutic implications. Cancer Res. 51: 4505-4510.

Chen, H.M. and L.M. Boxer. 1995. П1 binding sites are negative regulators of bcl-2 expression in pre-B cells. Mol. Cell. Biol. 15: $3840-3847$.

Coligan, J.E., A.M. Kruisbeek, D.H. Margulies, E.M. Shevach, and W. Strober, eds. 1991. Current protocols in immunology. Greene Publishing Associates, New York, NY.

Crabtree, G.R. 1989. Contingent genetic regulatory events in T lymphocyte activation. Science 243: 355-360.

Craig, R. 1995. The BCL-2 gene family. Semin. Cancer Biol. 6: $35-43$.

Evan, G.I., G.K. Lewis, G. Ramsay, and J.M. Bishop. 1985. Isolation of monoclonal antibodies specific for the human c-myc proto-oncogene product. Mol. Cell. Biol. 5: 3610 3616.

Evan, G.I., A.H. Wyllie, C.S. Gilbert, T.D. Littlewood, H. Land, M. Brooks, C.M. Waters, L.Z. Penn, and D.C. Hancock. 1992. Induction of apoptosis in fibroblasts by c-myc protein. Cell 69: 119-128.

Fang, W., J.J. Rivard, D.L. Mueller, and T.W. Behrens. 1994. Cloning and molecular characterization of mouse bcl-x in B and T lymphocytes. I. Immunol. 153: 4388-4398.

Foos, G., S. Grimm, and K.H. Klempnauer. 1992. Functional antagonism between members of the myb family: B-myb inhibits v-myb-induced gene activation. $E M B O J$. 11: 46194629.

Golay, J., A. Capucci, M. Arsura, M. Castellano, V. Rizzo, and M. Introna. 1991. Expression of c-myb and B-myb, but not A-myb, correlates with proliferation in human hematopoietic cells. Blood 77: 149-158.

Gonzalez Garcia, M., I. Garcia, L. Ding, S. O'Shea, L.H. Boise,
C.B. Thompson, and G. Nunez. 1995. bcl-x is expressed in embryonic and postnatal neural tissues and functions to prevent neuronal cell death. Proc. Natl. Acad. Sci. 92: 4304 4308.

Graf, T. 1992. Myb: A transcriptional activator linking proliferation and differentiation in hematopoietic cells. Curr. Opin. Genet. Dev. 2: 249-255.

Harrington, E.A., M.R. Bennett, A. Fanidi, and G.I. Evan. 1994. c-Myc-induced apoptosis in fibroblasts is inhibited by specific cytokines. EMBO J. 13: 3286-3295.

Herrmann, M., H.-M. Lorenz, R. Voll, M. Grunke, W. Woith, and J.R. Kalden. 1994. A rapid and simple method for the isolation of apoptotic DNA fragments. Nucleic Acids Res. 22: 5506-5507.

Hockenbery, D.M., M. Zutter, W. Hickey, M. Nahm, and S.J. Korsmeyer. 1991. BCL2 protein is topographically restricted in tissues characterized by apoptotic cell death. Proc. Natl. Acad. Sci. 88: 6961-6965.

Kishimoto, H., C.D. Surh, and J. Sprent. 1995. Upregulation of surface markers on dying thymocytes. J. Exp. Med. 181: 649655.

Korsmeyer, S.J. 1992. Chromosomal translocations in lymphoid malignancies reveal novel proto-oncogenes. Annu. Rev. Immunol. 10: 785-807.

Krieg, J., M. Oelgeschlager, R. Janknecht, and B. Luscher. 1995. High-affinity DNA-binding of native full-length c-myb and differentially proteolytic sensitivity of its $\mathrm{N}$-terminal and C-terminal domains. Oncogene 10: 2221-2228.

Lam, E.W. and R.J. Watson. 1993. An E2F-binding site mediates cell-cycle regulated repression of mouse B-myb transcription. EMBO J. 12: 2705-2713.

Lam, E., J. Bennett, and R. Watson. 1995. Cell-cycle regulation of human B-Myb transcription. Gene 160: 277-281.

Lin, D., M.T. Shields, S.J. Ullrich, E. Appella, and W.E. Mercer. 1992. Growth arrest induced by wild-type 553 protein blocks cells prior to or near the restriction point in late $G_{1}$ phase. Proc. Nat1. Acad. Sci. 89: 9210-9214.

Linette, G.P., M.J. Grusby, S.M. Hedrick, T.H. Hansen, L.H. Glimcher, and S.J. Korsmeyer. 1994. Bcl-2 is upregulated at the $\mathrm{CD} 4{ }^{+} \mathrm{CD} 8{ }^{+}$stage during positive selection and promotes thymocyte differentiation at several control points. Immunity 1: 197-205.

Littlewood, T.D., D.C. Hancock, P.S. Danielian, M.G. Parker, and G.I. Evan. 1995. A modified oestrogen receptor ligandbinding domain as an improved switch for the regulation of heterologous proteins. Nucleic Acids Res. 23: 1686-1690.

Melton, D.A., P.A. Krieg, M. Rebagliati, T. Maniatis, K. Zinn, and M.R. Green. 1984. Efficient in vitro synthesis of biologically active RNA and RNA hybridization probes from plasmids containing a bacteriophage SP6 promoter. Nucleic Acids Res. 12: 7035-7056.

Mettus, R.V., J. Litvin, A. Wali, A. Toscani, K. Latham, K. Hatton, and E.P. Reddy. 1994. Murine A-myb: Evidence for differential splicing and tissue-specific expression. Oncogene 9: 3077-3086.

Mountz, J.D., A.D. Steinberg, D.M. Klinman, and H.R. Smith. 1984. Autoimmunity and increased $c-m y b$ transcription. Science 226: 1087-1089.

Mucenski, M.L., K. McLain, A.B. Kier, S.H. Swerdlow, C.M. Schreiner, T.A. Miller, D.W. Pietryga, W.J. Scott, Jr. and S.S. Potter. 1991. A functional c-myb gene is required for normal murine fetal hepatic hematopoiesis. Cell 65: 677-689.

Nagata, S. and P. Golstein. 1995. The Fas death factor. Science 267: 1449-1456.

Nakagoshi, H., C. Kanei Ishii, T. Sawazaki, G. Mizuguchi, and S. Ishii. 1992. Transcriptional activation of the c-myc gene 
Taylor et al.

by the c-myb and B-myb gene products. Oncogene 7: 12331240.

Negrini, M., E. Silini, C. Kozak, Y. Tsujimoto, and C.M. Croce. 1987. Molecular analysis of mbcl-2: Structure and expression of the murine gene homologous to the human gene involved in follicular lymphoma. Cell 49: 455-463.

Ness, S.A., A. Marknell, and T. Graf. 1989. The v-myb oncogene product binds to and activates the promyelocyte-specific mim-l gene. Cell 59: 1115-1125.

Ohyashiki, K., J.H. Ohyashiki, A.J. Kinniburgh, K. Toyama, H. Ito, J. Minowada, and A. Sandberg. 1988. myb oncogene in human hematopoietic neoplasia with 6q- anomaly. Cancer Genet. Cytogenet. 33: 83-92.

Orlic, D., S. Anderson, L.G. Biesecker, B.P. Sorrentino, and D.M. Bodine. 1995. Pluripotent hematopoietic stem cells contain high levels of mRNA for c-kit, GATA-2, p45 NF-E2, and c-myb and low levels or no mRNA for c-fms and the receptors for granulocyte colony-stimulating factor and interleukins 5 and 7. Proc. Natl. Acad. Sci. 92: 4601-4605.

Pelicci, P.-G., L. Lanfrancone, M.D. Brathwaite, S.R. Wolman, and R. Dalla-Favera. 1984. Amplification of the c-myb oncogene in a case of human acute myelogenous leukemia. Science 224: 1117-1121.

Reiss, K., A. Ferber, S. Travali, P. Porcu, P.D. Phillips, and R. Baserga. 1991. The protooncogene c-myb increases the expression of insulin-like growth factor 1 and insulin-like growth factor 1 receptor messenger RNAs by a transcriptional mechanism. Cancer Res. 51: 5997-6000.

Roberts, S. and D.L. Bentley. 1992. Distinct modes of transcription read through or terminate at the c-myc attenuator. EMBO I. 11: 1085-1093.

Sala, A. and B. Calabretta. 1992. Regulation of BALB/c 3T3 fibroblast proliferation by B-myb is accompanied by selective activation of cdc2 and cyclin D1 expression. Proc. Natl. Acad. Sci. 89: 10415-10419.

Selvakumaran, M., H.K. Lin, R.T. Sjin, J.C. Reed, D.A. Liebermann, and B. Hoffman. 1994. The novel primary response gene MyD118 and the proto-oncogenes myb, myc, and bcl-2 modulate transforming growth factor beta l-induced apoptosis of myeloid leukemia cells. Mol. Cell. Biol. 14: 23522360.

Sentman, C.L., J.R. Shutter, D. Hockenbery, O. Kanagawa, and S.J. Korsmeyer. 1991. bcl-2 inhibits multiple forms of apoptosis but not negative selection in thymocytes. Cell 67: 879888.

Sheiness, D. and M. Gardinier. 1984. Expression of a proto-oncogene (proto-myb) in hemopoietic tissues of mice. Mol. Cell. Biol. 4: 1206-1212.

Sitzmann, J., K. Noben-Trauth, and K.-H. Klempnauer. 1995. Expression of mouse c-myb during embryonic development. Oncogene 11: 2273-2279.

Smarda, J. and J.S. Lipsick. 1994. c-Myb prevents TPA-induced differentiation and cell death in v-Myb transformed monoblasts. Oncogene 9: 237-245.

Stern, J.B. and K.A. Smith. 1986. Interleukin-2 induction of $\mathrm{T}$-cell $\mathrm{G}_{1}$ progression and $\mathrm{c}-\mathrm{myb}$ progression. Science 233: 203-206.

Strasser, A., A.W. Harris, D.L. Vaux, E. Webb, M.L. Bath, J.M. Adams, and S. Cory. 1990. Abnormalities of the immune system induced by dysregulated bcl-2 expression in transgenic mice. Curr. Top. Microbiol. Immunol. 166: 175-181.

Strasser, A., A.W. Harris, and S. Cory. 1991. bcl-2 transgene inhibits $\mathrm{T}$ cell death and perturbs thymic self-censorship. Cell 67: 889-899.

Strasser, A., A.W. Harris, D.C.S. Huang, P.H. Krammer, and S. Cory. 1995. Bcl-2 and Fas/APO-1 regulate distinct pathways to lymphocyte apoptosis. EMBO J. 14: 6136-6147.

Tashiro, S., Y. Takemoto, H. Handa, and S. Ishii. 1995. Cell type-specific trans-activation by the B-myb gene product: Requirement of the putative cofactor binding to the C-terminal conserved domain. Oncogene 10: 1699-1707.

Tesch, H., M. Michels, M. Jucker, I. Pahl, S. Klein, H. Bading, K. Moelling, and V. Diehl. 1992. Heterogeneous expression of c-myb protein in human leukemia detected by simultaneous two color flow cytometric analysis. Leuk. Res. 16: 265-274.

Thompson, M.A. and R.G. Ramsay. 1995. Myb: An old oncoprotein with new roles. Bioessays 17: 341-350.

Thompson, C.B., P.B. Challoner, P.E. Neiman, and M. Groudine. 1986. Expression of the c-myb proto-oncogene during cellular proliferation. Nature 319: 374-380.

Veis, D.J., C.L. Sentman, E.A. Bach, and S.J. Korsmeyer. 1993. Expression of the Bcl-2 protein in murine and human thymocytes and in peripheral $\mathrm{T}$ lymphocytes. I. Immunol. 151: 2546-2554.

Thompson, C.B., P.B. Challoner, P.E. Neiman, and M. Groudine. 1986. Expression of the c-myb proto-oncogene during cellular proliferation. Nature 319: 374-380.

Weston, K.M. 1990. The myb genes. Semin. in Cancer Biol. 1: 371-382.

Weston, K. and J.M. Bishop. 1989. Transcriptional activation by the v-myb oncogene and its cellular progenitor, c-myb. Cell 58: 85-93.

Young, R.L. and S.J. Korsmeyer. 1993. A negative regulatory element in the bcl-2 5'-untranslated region inhibits expression from an upstream promoter. Mol. Cell. Biol. 13: 36863697. 


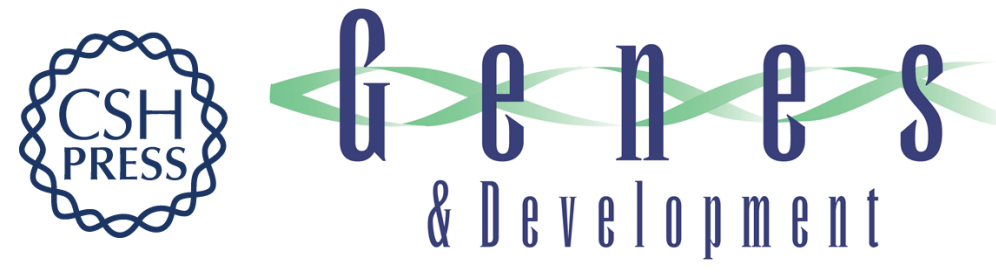

\section{A dominant interfering Myb mutant causes apoptosis in T cells.}

D Taylor, P Badiani and K Weston

Genes Dev. 1996, 10:

Access the most recent version at doi:10.1101/gad.10.21.2732

References This article cites 62 articles, 27 of which can be accessed free at: http://genesdev.cshlp.org/content/10/21/2732.full.html\#ref-list-1

License

Email Alerting Receive free email alerts when new articles cite this article - sign up in the box at the top Service right corner of the article or click here.

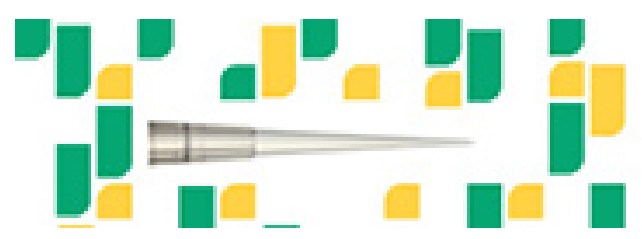

Focused on your science.

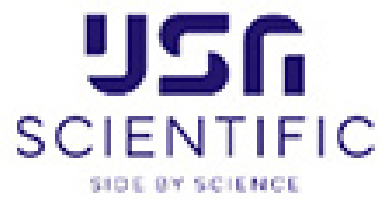

Copyright @ Cold Spring Harbor Laboratory Press 